Збірник наукових статей

Михаил Медвидь, Анатолий Бабичев, Владимир Демьянишин, Ярослав Павлов. Управление изменениями в военных системах высшего образования и профессиональной ориентации.

Проведен анализ современного состояния высшего образования Украинь. Обосновань мероприятия управления изменениями $в$ военных системах высшего образования и профессиональной ориентации по осуществлению переподготовки военнослужащих $к$ миротворческой деятельности и профессиональной ориентации школьников на военную службу по контракту путем преподавания офииерами предмета «Зашита Отечества».

Ключевые слова: высшее образование, управление изменениями, профессиональная ориентация.

Mykhailo Medvid, Anatoliy Babichev, Volodymyr Demianyshyn, Yaroslav Pavlov. Management of changes in military systems of higher education and professional orientation.

The analysis of modern condition higher education in Ukraine was conducted. Substantiated the change management activities in the military systems of higher education and professional orientation the implementation of military training for peacekeeping activities and professional orientation of pupils to military service under the contract by the teaching of the subject officers "Defense of the Motherland».

Keywords: higher education, change management, professional orientation.

Стаття надійшла до редакційної колегії 26.09.2016

УДК 37.091.321+355.23-047.22

(С) Мельник Ю. Б., 2016

Мельник Юрій Борисович

Національна академія Національної гвардії України

\title{
ДОСЛІДЖЕННЯ СОЦІАЛЬНОГО ЗАПИТУ КУРСАНТІВ І СТУДЕНТІВ ЩОДО ФОРМУВАННЯ КОМПЕТЕНТНОСТЕЙ У ВВНЗ
}

Розглянуто Закон України «Про вищу освіту» відносно правових $i$ організачійних засад функціонування вищих військових навчальних закладів. Уточнено сутність поняття «компетентність». Висвітлено європейський досвід класифікації компетентностей. Наведено результати дослідження соціального запиту курсантів $i$ студентів щодо формування у них загальних компетентностей викладачами Наиіональної академії Національної гвардї Украӥни. 
Ключові слова: вищий військовий навчальний заклад, сочіальний запит, компетентність, класифікація компетентностей, інструментальні компетентності, міжособистісні компетентності, системні компетентності, результати навчання, проект Тюнінг.

В останнє десятиріччя відбувається інтенсивне реформування системи вищої освіти в Україні, під час якого досягнуто істотних результатів. Масштабність запроваджених нововведень передбачає їх подальшу систематизацію та дослідження численних складників, а також імплементацію задекларованих положень згідно 3 новою редакцією Закону України «Про вищу освіту» [1]. Особливої актуальності ця проблема набуває у вищих військових навчальних закладах (далі - ВВНЗ).

В п. 6, ч. 1, ст. 1 Закону України «Про вищу освіту» зазначено, що «вищий військовий навчальний заклад (вищий навчальний заклад iз специфічними умовами навчання) - вищий навчальний заклад державної форми власності, який здійснює на певних рівнях вищої освіти підготовку курсантів (слухачів, студентів), ад'юнктів для подальшої служби на посадах офіцерського (сержантського, старшинського) або начальницького складу 3 метою задоволення потреб Міністерства внутрішніх справ України, Збройних Сил України...» [1]. Цей Закон встановлює основні правові, організаційні, фінансові засади функціонування системи вищої освіти, створює умови для посилення співпраці державних органів і бізнесу з вищими навчальними закладами на принципах автономії вищих навчальних закладів, поєднання освіти 3 наукою та виробництвом 3 метою підготовки конкурентоспроможного людського капіталу для високотехнологічного та інноваційного розвитку країни, самореалізації особистості, забезпечення потреб суспільства, ринку праці та держави у кваліфікованих фахівцях. У ньому наголошується, що підготовка фахівців 3 вищою освітою має здійснюватися 3 урахуванням потреб особи, інтересів держави, громади і роботодавців.

Отже, одним із завдань, яке суспільство й держава ставить перед ВВН3, є з'ясування соціального запиту щодо формування у курсантів/студентів компетентностей під час їхнього навчання.

Задля вирішення цього завдання нами проведено дослідження соціального запиту курсантів і студентів щодо формування загальних компетентностей викладачами Національної академії Національної гвардії України (далі - НА НГУ).

Мета статті - висвітлити європейський досвід класифікації компетентностей, результати дослідження соціального запиту курсантів і студентів щодо формування у них компетентностей викладачами НА НГУ. 


\section{Збірник наукових статей}

Важливим є визначення базового терміну - компетентність.

Компетентність ми розуміємо як загальну здатність, що базується на здібностях, знаннях, цінностях та досвіду, набутому завдяки навчанню, проявляється в результатах навчання на певному етапі.

Запропоноване нами уточнення визначення «компетентність» потребує з'ясування взаємозв'язку з такою його складовою ознакою, як результати навчання. Оскільки ці категорії $є$ дуже близькими за своєю сутністю, так як обидві стосуються формування у студентів знань, умінь, навичок тощо.

Результати навчання - закладають викладачі в зміст освітніх програм, тоді як компетентності, якими повинен оволодіти випускник ВН3, замовляють працедавці. Результати навчання мають бути чітко вимірюваними в рамках програми одного рівня вищої освіти, на відміну від компетентностей, які набуваються поступово, формуються цілою низкою навчальних дисциплін або модулів на різних етапах програми, і навіть рівнях вищої освіти.

Отже, компетентності набуваються студентами і формуються викладачами як на рівні окремої дисципліни, так і освітньої програми в цілому. Ця теза є важливим вихідним положенням для формулювання мети - дослідження соціального запиту курсантів і студентів щодо формування у них компетентностей викладачами у ВВНЗ.

Основними джерелами інформації щодо класифікації та дослідження компетентностей, на які ми будемо спиратися в цій статті, $€$ матеріали Агенції забезпечення якості вищої освіти Сполученого Королівства (The Quality Assurance Agency for Higher Education, QAA, UK) та європейського проекту Тюнінг (Tuning educational structures in Europe, TUNING) [2].

Саме дослідження компетентностей було одним із найважливіших завдань проекту Тюнінг, який ініційований у 2000 р. європейськими університетами (координатор - Університет Деусто, Іспанія) за активної підтримки Європейської Комісії. Протягом подальших років цей проект доповнений низкою регіональних проектів: Тюнінг - Латинська Америка (2003р.), Тюнінг - Росія (2006 р.), Тюнінг - США, Тюнінг - Литва, Тюнінг - Африка, Тюнінг Австралія (2009р.). Слід зазначити, що 3 метою розроблення секторальних (галузевих) Рамок кваліфікацій та узгоджених їx iз Рамкою кваліфікацій Свропейського простору вищої освіти, у 2007 р. запроваджено спеціалізований проект - Tuning SQF.

Розповсюдженою є думка, що визначення компетентностей $€$ привілеєм експертів і викладачів, також не завадить врахування запиту працедавців. Однак, не слід забувати про студентів, які сьогодні стають більш мобільними та формують попит, як на певні 
спеціальності, так і висувають власні вимоги щодо формування у них чітких компетентностей.

Загальноприйнятий розподіл компетентностей на дві групи: предметно-спеціальні (фахові) (subject specific competences) та загальні (generic competences, transferable skills) потребував уточнення та конкретизації.

На основі досвіду більше 100 університетів з 16 країн-учасниць Болонського процесу (у консультаціях та опитуваннях взяли участь 5183 випускників, 998 професорів, 944 працедавців) відібрано 30 загальних компетентностей 3 трьох категорій: інструментальні, міжособистісні і системні. Вони класифіковані з точки зору значення навичок для професії i рівня опанування після закінчення програми $[2 ; 3]$.

1. Конкретизований набір інструментальних компетентностей включає: когнітивні, методологічні, технологічні та лінгвістичні здатності, а саме: здатність до аналізу i синтезу; здатність до організації і планування; базові загальні знання; засвоєння основ базових знань з професії; усне і письмове спілкування рідною мовою; знання другої мови; елементарні комп'ютерні навички; навички управління інформацією (уміння знаходити та аналізувати інформацію 3 різних джерел); розв’язання проблем; прийняття рішень.

2. Конкретизований набір міжособистісних компетентностей включає: навички спілкування, соціальну взаємодію та співпрацю, а саме: здатність до критики та самокритики; взаємодія (робота в команді); міжособистісні навички та вміння; здатність працювати в міждисциплінарній команді; здатність спілкуватися 3 експертами 3 інших галузей; позитивне ставлення до несхожості та інших культур; здатність працювати в міжнародному середовищі; етичні зобов’язання.

3. Конкретизований набір системних компетентностей включає: поєднання розуміння, сприйнятливості та знань, здатність планування змін для удосконалення систем, розроблення нових систем, а саме: здатність застосовувати знання на практиці; дослідницькі навички і уміння; здатність до навчання; здатність пристосовуватись до нових ситуацій; здатність породжувати нові ідеї (креативність); лідерські якості; розуміння культури та звичаїв інших країн; здатність працювати самостійно; планування та управління проектами; ініціативність і дух підприємництва; турбота про якість; бажання досягти успіху.

Для 3'ясування соціального запиту тих, хто навчається, підготовки фахівців із вищою освітою з урахуванням потреб особи, інтересів держави, територіальних громад і роботодавців курсантам i студентам НА НГУ було запропоновано обрати з 30 вищенаведених 


\section{Збірник наукових статей}

загальних компетентностей ті, які, на їхню думку, мають формувати у них викладачі ВВНЗ.

Опитування проводилось упродовж 3-х навчальних років (20132016 р.p.) анонімно у письмовій формі. Загальна вибірка була достатньо репрезентативною. Курсантам і студентам з 18 груп денної форми, четвертого року навчання, запропоновано зробити індивідуальний вибір 5 найбільш важливих компетентностей iз вищезазначеного переліку та проранжувати їх. На наступному етапі кожний учасник мав можливість обговорити свій вибір у групах, визначивши при цьому спільних 5 компетентностей. На останньому етапі відбувалося колективне обговорення результатів роботи у групах й ухвалення переліку 35 найвагоміших компетентностей 3 встановленням їх ієрархї̈.

Ці дані кожний учасник заносив у таблицю (таблиця 1).

Таблиця 1

Інструментарій дослідження соціального запиту щодо компетентностей

\begin{tabular}{|c|c|c|c|c|}
\hline $\begin{array}{c}\text { № } \\
\text { 3/П }\end{array}$ & $\begin{array}{c}\text { Назва } \\
\text { компетентностей }\end{array}$ & $\begin{array}{c}\text { Вибір 1 } \\
\text { (індивідуальний) }\end{array}$ & $\begin{array}{c}\text { Вибір 2 } \\
\text { (груповий) }\end{array}$ & $\begin{array}{c}\text { Вибір 3 } \\
\text { (колективний) }\end{array}$ \\
\hline 1. & & & & \\
\hline 2. & & & & \\
\hline 3. & & & & \\
\hline 4. & & & & \\
\hline 5. & & & & \\
\hline$\ldots$ & & & & \\
\hline
\end{tabular}

Загальні результати дослідження соціального запиту в навчальних групах, відповідно до вищезазначених загальних компетентностей 3 трьох категорій, наведені в таблиці 2.

Отримані результати свідчать, що найбільш затребуваними серед курсантів і студентів НА НГУ $є$ попит на формування у них викладачами таких компетентностей:

- базові знання з професії;

- уміння організовувати і планувати;

- здатність приймати рішення;

- здатність застосовувати знання на практиці;

- здатність адаптуватися до нових ситуацій;

- здатність працювати в команді;

- відповідальність за якість;

- прагнення до успіху.

Запит на інші компетентності слабо виражений або відсутній зовсім. 
Результати дослідження соціального запиту курсантів і студентів щодо формування у них загальних компетентностей у ВВНЗ

\begin{tabular}{|c|c|c|c|c|c|c|c|c|c|c|c|c|c|c|c|c|c|c|c|}
\hline $\begin{array}{l}\text { № } \\
\text { 3/ח }\end{array}$ & $\begin{array}{c}\text { Назва } \\
\text { компетентностей }\end{array}$ & กิ & 8 & 号 & 足 & $\stackrel{\circ}{2}$ & $\stackrel{8}{\circ}$ & $\frac{0}{m}$ & స్ & $\bar{n}$ & 寻 & $\bar{n}$ & $\bar{m}$ & $\vec{\sim}$ & $\frac{N}{m}$ & 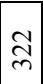 & $\underset{7}{\stackrel{V}{\gamma}}$ & $\tilde{n}$ & ర్ \\
\hline \multirow{9}{*}{ 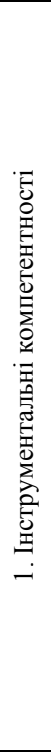 } & $\begin{array}{l}\text { 1) здатність до } \\
\text { аналізу та синтезу; }\end{array}$ & & & & & & & & & 2 & & & & & & & & & \\
\hline & $\begin{array}{l}\text { 2) уміння } \\
\text { організовувати і } \\
\text { планувати; }\end{array}$ & & & 2 & & & 2 & 3 & 3 & 4 & 4 & & & 1 & & 4 & 2 & 3 & \\
\hline & $\begin{array}{l}\text { 3) базові загальні } \\
\text { знання; }\end{array}$ & & & & & & & & & & & & & & & & & & \\
\hline & $\begin{array}{l}\text { 4) базові знання } 3 \\
\text { професії; }\end{array}$ & 5 & 1 & 1 & 1 & 1 & 1 & & & 1 & & & & & & & & 1 & \\
\hline & $\begin{array}{l}\text { 5) комунікативні } \\
\text { навички з рідної } \\
\text { мови; }\end{array}$ & & & & & & & & & & & & & & & & & & \\
\hline & $\begin{array}{l}\text { 6) елементарні } \\
\text { комп'ютерні } \\
\text { навички; } \\
\end{array}$ & & & & 2 & & & & & & & & & & & & & & 2 \\
\hline & $\begin{array}{l}\text { 7) навички } \\
\text { оперування } \\
\text { інформацією; }\end{array}$ & & & & & & & & & & & & & & & & & & \\
\hline & $\begin{array}{l}\text { 8) здатність } \\
\text { вирішувати } \\
\text { проблеми; }\end{array}$ & 1 & & & & & & & & & 1 & & 2 & 4 & & 1 & 4 & & \\
\hline & $\begin{array}{l}\text { 9) здатність } \\
\text { приймати рішення. }\end{array}$ & 2 & 5 & 5 & & 4 & & & & 3 & 3 & 4 & 3 & & 4 & 2 & 3 & & \\
\hline \multirow{6}{*}{ 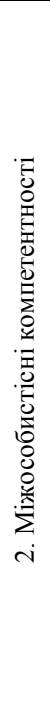 } & $\begin{array}{l}\text { 1) здатність до } \\
\text { критики та } \\
\text { самокритики; } \\
\end{array}$ & & & & & & & & & & & & & & & 5 & & & \\
\hline & $\begin{array}{l}\text { 2) здатність } \\
\text { працювати в } \\
\text { команді; }\end{array}$ & & & 3 & 4 & & 4 & 2 & 2 & & & 5 & & & 2 & & & 2 & 4 \\
\hline & $\begin{array}{l}\text { 3) міжособистісні } \\
\text { навички; }\end{array}$ & & & & & & & & & & & & & & & & & & \\
\hline & $\begin{array}{l}\text { 4) здатність } \\
\text { працювати в } \\
\text { міждисциплінарні } \\
\text { й команді; }\end{array}$ & & & & & & & & & & & & & & & & & & \\
\hline & $\begin{array}{l}\text { 5) здатність } \\
\text { співпрацювати з } \\
\text { експертами в } \\
\text { інших предметних } \\
\text { областях; }\end{array}$ & & & & & & & & & & & & & & & & & & \\
\hline & $\begin{array}{l}\text { 6) здатність } \\
\text { сприймати } \\
\text { різноманітність та } \\
\text { міжкультурні } \\
\text { відмінності; }\end{array}$ & & & & & & & & & & & & & & & & & & \\
\hline
\end{tabular}


Продовж. табл. 2.

\begin{tabular}{|c|c|c|c|c|c|c|c|c|c|c|c|c|c|c|c|c|c|c|c|}
\hline & $\begin{array}{l}\text { 7) здатність } \\
\text { працювати в } \\
\text { міжнародному } \\
\text { контексті; }\end{array}$ & & & & & & & & & & & & & & & & & & \\
\hline & $\begin{array}{l}\text { 8) прихильність до } \\
\text { етичних цінностей. }\end{array}$ & & & & & & & & & & & & & & & & & & \\
\hline \multirow{12}{*}{ 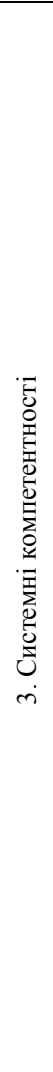 } & $\begin{array}{l}\text { 1) здатність } \\
\text { застосовувати } \\
\text { знання на } \\
\text { практиці; }\end{array}$ & 3 & 2 & & 3 & 3 & 3 & 1 & 1 & 5 & & 2 & 4 & 2 & 1 & & & 4 & 1 \\
\hline & $\begin{array}{l}\text { 2) дослідницькі } \\
\text { здібності; }\end{array}$ & & & & & & & & & & & & & & & & & & \\
\hline & $\begin{array}{l}\text { 3) здібність до } \\
\text { навчання; }\end{array}$ & & & & & & & & & & 5 & & & & & & & & \\
\hline & $\begin{array}{l}\text { 4) здатність } \\
\text { адаптуватися до } \\
\text { нових ситуацій; }\end{array}$ & 4 & & & & 2 & & 5 & 5 & & 2 & & 1 & 3 & & & & & \\
\hline & $\begin{array}{l}\text { 5) здатність } \\
\text { генерування нових } \\
\text { ідей (творчості); }\end{array}$ & & & & & & & & & & & & & & & & & & \\
\hline & $\begin{array}{l}\text { 6) здатність до } \\
\text { лідерства; }\end{array}$ & & & & & & & & & & & & & & & 3 & 1 & & 3 \\
\hline & $\begin{array}{l}\text { 7) розуміння } \\
\text { культур та звичаїв } \\
\text { інших країн; }\end{array}$ & & & & & & & & & & & & & & & & & & \\
\hline & $\begin{array}{l}\text { 8) здатність } \\
\text { працювати } \\
\text { автономно; }\end{array}$ & & & & & & & & & & & & & & & & & & \\
\hline & $\begin{array}{l}\text { 9) здатність до } \\
\text { розробки проектів } \\
\text { та керування } \\
\text { ними; }\end{array}$ & & & & & & & & & & & & & & & & & & \\
\hline & $\begin{array}{l}\text { 10) здатність до } \\
\text { ініціативи і } \\
\text { підприємництва; }\end{array}$ & & & & & & & & & & & 1 & & & & & & 5 & \\
\hline & $\begin{array}{l}\text { 11) відповідаль- } \\
\text { ність за якість; }\end{array}$ & & 4 & & 5 & & & & & & & & 5 & 5 & 5 & & & & \\
\hline & $\begin{array}{l}\text { 12) прагнення до } \\
\text { успіху. }\end{array}$ & & 3 & 4 & & 5 & 5 & 4 & 4 & & & 3 & & & 3 & & 5 & & 5 \\
\hline
\end{tabular}

Висновки. Між результатами навчання, які закладають викладачі в зміст освітніх програм та компетентностями, якими повинен оволодіти випускник ВНЗ, існує кореляційний зв'язок. Результати проведеного дослідження свідчать що затребуваними є лише окремі компетентності, що можна пояснити специфікою навчального закладу та реаліями сьогодення України. Вірно визначені компетентності у діяльності викладачів $\epsilon$ системоутворюючим чинником процесу підготовки молодого фахівця. 
Проведене дослідження не вичерпує всіх аспектів вирішення проблеми дослідження компетентностей у ВВН3. Подальшого дослідження потребують питання: 3'ясування запиту Міністерств та відомств, соціального запиту працедавців, узгодження переліку цих компетентностей 3 експертами тощо. Важливим $\epsilon$ узгодження компетентностей відповідно до освітніх програм, які формуються в різних навчальних дисциплінах і оцінюються на різних етапах.

\section{Література}

1. Закон України «Про вищу освіту» від 01.07.2014 № 1556-VII [Електронний ресурс] // Вища освіта. Інформаційно-аналітичний портал про вищу освіту в Україні та за кордоном. - Режим доступу : http://vnz.org.ua/zakonodavstvo. - Назва з титул. екрану.

2. Розроблення освітніх програм. Методичні рекомендації / Авт. : $\quad$ В. М. Захарченко, В. І. Луговий, Ю. М. Рашкевич, Ж. В. Таланова / За ред. В. Г. Кременя. - К. : ДП «НВЦ «Пріоритети», 2014. $-120 \mathrm{c}$.

3. Процес європейської інтеграції впливає на всі сфери життя держави: Україна чітко визначила орієнтири на входження в освітній та науковий простір Європи [Електронний ресурс]. - Режим доступу : http://bibl.com.ua/bank/356/index.html?page=18. - Назва 3 титул. екрану.

\section{Юрий Мельник. Исследование социального запроса} курсантов и студентов по формированию компетентности в ВВУЗ. Рассмотрен Закон Украины «О выстем образовании» относительно правовых и организаџионных основ функционирования высших военных учебных заведений. Уточнена сущность понятия «компетентность». Освещен европейский опыт классификаиии компетентностей. Представлень результаты исследования социального запроса курсантов и студентов по формированию $у$ них общих компетентностей преподавателями Национальной академии Начиональной гвардии Украиньл.

Ключевые слова: высшее военное учебное заведение, социальный запрос, компетентность, классификачия компетентностей, инструментальные компетентности, межличностные компетентности, системные компетентности, результать обучения, проект Тюнинг.

Yuriy Melnyk. The study of social inquiry cadets and students on formation of competence in HMEI.

Considered the Law of Ukraine «On Higher Education» on the legal and organizational basis of functioning of the higher military educational institutions. Refined essence of «competence» concept. Illuminated by the European experience of classification of competencies. Presents the results of the study of social inquiry cadets and students on formation of their 
general competence of the teachers of the National Academy of the National Guard of Ukraine.

Keywords: higher military educational institution, social inquiry, competence, competence classification, instrumental competence, interpersonal competence, system competence, learning outcomes, the project Tuning.

Стаття надійшла до редакційної колегії 01.09.2016

УДК 378.016:004.056.5

\section{Мельник Сергій Володимирович}

(C) Мельник С. В., 2016 Національна академія Служби безпеки України

\section{ДІЯЛЬНІСНИЙ АСПЕКТ ПОБУДОВИ КОМПЕТЕНТНІСНОЇ МОДЕЛІ МАЙБУТНЬОГО ФАХІВЦЯ З КІБЕРБЕЗПЕКИ}

Проаналізовано понятійно-категоріальний апарат дослідження проблеми побудови компетентнісної моделі майбутнього фахівия 3 кібербезпеки, визначено структуру моделі та сутність діяльнісного підходу до ї̈ побудови.

Ключові слова: компетентність та компетенція, компетентнісна модель майбутнього фахівия з кібербезпеки, модель професійної діяльності майбутнього фахівия з кібербезпеки.

Професійна підготовка фахівців для сфери кібербезпеки є одним iз актуальних напрямів розвитку вищої освіти, орієнтованого на кадрове забезпечення високотехнологічних виробництв та інноваційних напрямів професійної діяльності в Україні. Про це свідчить і факт впровадження в Україні нової спеціальності 125 «Кібербезпека» галузі знань 12 «Інформаційні технології» відповідно до «Переліку галузей знань і спеціальностей, за якими здійснюється підготовка здобувачів вищої освіти», що затверджений Постановою КМ України від 29 квітня 2015 року № 266.

Кібербезпека як явище, сфера професійної та наукової діяльності базується на міжпредметній компетентності, включаючи технічну, юридичну, психологічну та інші складові. Враховуючи достатню новизну зазначеної сфери професійної діяльності та динаміку розвитку ринку праці в приватному і державному секторах, проблема якісної професійної підготовки фахівців 3 кібербезпеки $є$ одним із актуальних напрямів наукових досліджень у педагогічній науці. 